\title{
Allium compounds, dipropyl and dimethyl thiosulfinates as antiproliferative and differentiating agents of human acute myeloid leukemia cell lines
}

\author{
Faten Merhi' \\ Jacques Auger ${ }^{2}$ \\ Francine Rendu' \\ Brigitte Bauvois' \\ 'UMR 7I3I UPMC Paris Universitas/ \\ CNRS, Groupe Hospitalier \\ Broussais-HEGP, Paris, France; \\ ${ }^{2}$ University F. Rabelais, IRBI, UPRESA \\ CNRS 6035, Tours, France
}

\begin{abstract}
Epidemiologic studies support the premise that Allium vegetables may lower the risk of cancers. The beneficial effects appear related to the organosulfur products generated upon processing of Allium. Leukemia cells from patients with acute myeloid leukemia (AML) display high proliferative capacity and have a reduced capacity of undergoing apoptosis and maturation. Whether the sulfur-containing molecules thiosulfinates (TS), diallyl TS (All 2 TS), dipropyl TS ( $\left.\mathrm{Pr}_{2} \mathrm{TS}\right)$ and dimethyl TS $\left(\mathrm{Me}_{2} \mathrm{TS}\right)$, are able to exert chemopreventative activity against AML is presently unknown. The present study was an evaluation of proliferation, cytotoxicity, differentiation and secretion of AML cell lines (U937, NB4, HL-60, MonoMac-6) in response to treatment with these TS and their related sulfides (diallylsulfide, diallyl disulfide, dipropyl disulfide, dimethyl disulfide). As assessed by flow cytometry, ELISA, gelatin zymogaphy and RT-PCR, we showed that $\operatorname{Pr}_{2}$ TS and $\mathrm{Me}_{2} \mathrm{TS}$, but not All ${ }_{2} \mathrm{TS}$ and sulfides, 1) inhibited cell proliferation in dose- and time-dependent manner and this process was neither due to cytotoxicity nor apoptosis, 2) induced macrophage maturation, and 3) inhibited the levels of secreted MMP-9 (protein and activity) and TNF- $\alpha$ protein, without altering mRNA levels. By establishing for the first time that $\mathrm{Pr}_{2} \mathrm{TS}$ and $\mathrm{Me}_{2} \mathrm{TS}$ affect proliferation, differentiation and secretion of leukemic cell lines, this study provides the opportunity to explore the potential efficiency of these molecules in AML.

Keywords: acute myeloid leukemia, thiosulfinate, proliferation, differentiation, matrix metalloproteinase-9
\end{abstract}

\section{Introduction}

Acute myeloid leukemia (AML) is a deadly disease, resulting from the clonal expansion and accumulation of hematopoietic stem cells arrested at various stages of development (Mason et al 2006; Plesa et al 2008). Leukemia cells are unable to undergo growth arrest, terminal differentiation and apoptosis in response to appropriate environmental stimuli, and prematurely egress from the bone marrow to disseminate into peripheral tissues (Mason et al 2006; Plesa et al 2008). The standard approach to AML remains chemotherapy, and the novel agents currently available (multidrug resistance inhibitors, farnesyltransferase inhibitors, receptor kinase inhibitors, monoclonal CD33 antibody-mediated drugs) (King et al 2007; Thomas et al 2007) show some efficacy in either monotherapy or in combination with conventional chemotherapeutic drugs such as anthracycline, cytarabine or idarubicin (Adachi et al 2004; Leone et al 2006; Thomas et al 2007). The development of new compounds directed against leukemia-specific targets is however needed to increase the cure rate in AML patients exhibiting chemoresistance and poor outcomes.

Allium vegetables (including garlic, onions, leeks, chives, and scallions) are used throughout the world for their sensory characteristics as well as their apparent health benefits (Amagase 2006; Borek 2006; Milner 2006). They exhibit antimicrobial, 
antithrombotic, antitumor, antiarthritic and hypoglycemic properties (Ackermann et al 2001; Pinto et al 2001; Khanum et al 2004; Amagase 2006; Borek 2006; Milner 2006) which are largely attributed to the presence of sulfur compounds in these plants (Le Bon et al 2000; Lanzotti 2006). For example, the major sulfur-containing molecules in intact garlic are sulfoxides, which are converted into thiosulfinates (such as Allicin) when raw garlic is cut or crushed (Amagase 2006; Lanzotti 2006). Allicin (diallyl thiosulfinate/All TS) (Figure 1 ) is rapidly decomposed to diallyldisulfide (DADS) (Figure 1), diallylsulfide (DAS) (Figure 1), diallyltrisulfide (DATS) (Figure 1) and sulfur dioxide, and therefore does not seem to be a genuine active compound of garlic (Amagase 2006). DADS and DATS exert antiproliferative and proapoptotic effects in human epithelial cancer and neuronal cell lines (Sundaram et al 1996b; Pinto et al 2001; Hosono et al 2005; Milner 2006; Xiao et al 2005, 2006). DADS induces apoptosis in the leukemic HL-60 cell line through activation of caspase-3 (Kwon et al 2002), and inhibits NO synthesis in LPS-activated macrophages (Ippoushi et al 2002). DATS also stimulates apoptosis of HL-60 cells (Zheng et al 1997) and inhibits platelet function by inhibiting platelet aggregation and $\mathrm{Ca}(2+)$ mobilization (Qi et al 2000). Other thiosulfinates such as dipropyl thiosulfinate $\left(\mathrm{Pr}_{2} \mathrm{TS}\right)$ and dimethyl thiosulfinate ( $\mathrm{Me}_{2} \mathrm{TS}$ ) (Figure 1) are mainly identified in onion and leek (Lanzotti 2006). $\operatorname{Pr}_{2}$ TS, Me 2 TS

Thiosulfinates (TS)

Disulfides (DS)

Sulfides

$\mathbf{R}$

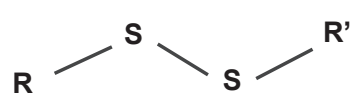

Me2 TS, DMDS : R, R' : CH3-

Pr2 TS, DPDS: R, R' : CH3-CH2-CH2-

\section{All2TS, DADS, DAS: R, R' : $\mathrm{CH} 2=\mathrm{CH}-\mathrm{CH} 2-$}

Figure I Structure of thiosulfinates and sulfides used in this study. Abbreviations: DADS, Diallyl disulfide; DAS, diallylsulfide; All ${ }_{2} T S$, diallyl thiosulfinate; DMDS, dimethyl disulfide; $\mathrm{Me}_{2} \mathrm{TS}$, dimethyl thiosulfinate; DPDS, dipropyl disulfide; $\mathrm{Pr}_{2} \mathrm{TS}$, dipropyl thiosulfinate. and $\mathrm{All}_{2} \mathrm{TS}$ are found to inhibit platelet aggregation through inhibition of calpain (Rendu et al 2001), by reaction with surface free sulfhydryls and internal thiol-containing proteins (Badol et al 2007).

Whether $\operatorname{Pr}_{2}$ TS, Me 2 TS and All TS are able to exert chemopreventative activity against AML is presently unknown. With the above in mind, we undertook this study to evaluate the in vitro efficacy of these compounds on human cell lines representative of AML. We show that $\mathrm{Pr}_{2}$ TS and $\mathrm{Me}_{2}$ Ts, but not All 2 TS and their related sulfides, inhibit the growth of AML cell lines and interfere with the secretion of tumor necrosis factor- $\alpha$ (TNF- $\alpha$ ) and matrix metalloproteinase-9 (MMP-9). Additional studies are warranted to investigate the inhibitory activity of $\operatorname{Pr}_{2} \mathrm{TS}$ and $\mathrm{Me}_{2} \mathrm{TS}$ in AML patients' cells ex vivo.

\section{Materials and methods}

\section{Chemicals and antibodies}

Monoclonal antibodies (mAbs) (fluorescein isothiocyanate, FITC; phycoerythrin, PE) specific for CD11b (mIgG1, BEAR1), CD13 (mIgG1, SJ1D1), CD15 (mIgM, 80H5), CD44 (mIgG1, J-173), Apo 2.7 (mIgG1, 27AGA3), their isotypes and the Annexin V-FITC staining kit were obtained from Coulter/Beckman (Luminy, France). Irrelevant mouse (m)IgGs (FITC and PE) were obtained from R\&D (Adbington, UK). Phorbol myristate acetate (PMA), nigericin, dimethyl disulfide (DMDS), dipropyl disulfide (DPDS), diallylsulfide (DAS), and diallyl disulfide (DADS) were obtained from Sigma-Aldrich (Saint Louis, MO, USA). Diallyl thiosulfinate (All ${ }_{2} \mathrm{TS}$ ), dipropyl thiosulfinate ( $\mathrm{Pr}_{2} \mathrm{TS}$ ) and dimethyl thiosulfinate ( $\left.\mathrm{Me}_{2} \mathrm{TS}\right)$ were synthesized as previously described (Auger et al 1990). Organosulfurcompounds were solubilized in water. The stability of TS was assessed by HPLC analysis (Arnault et al 2003). Alltrans retinoic acid was provided by Ares-Serono (Geneva, Switzerland).

\section{Human AML cell lines and cell culture}

Models of AML were represented by U937 cell line (monoblastic stage, AML-M5) (Ferrara et al 2001) (American Tissue Cell Culture), HL-60 cell line (promyelocytic stage, AML-M2) (Drexler et al 1999) (American Tissue Cell Culture), NB4 cell line (promyelocytic stage, AML-M3) (Lanotte et al 1991) (a gift from Dr Lanotte, Hôpital Saint Louis, Paris, France) and MonoMac-6 (promonocytic stage, AML-M5) (Drexler et al 2004) (a gift from Dr Ziegler-Heitbrock, University of Munich, Germany). Cells were maintained in RPMI 1640 medium 
supplemented with 5\% heat-inactivated fetal calf serum (FCS; Gibco, Paisley, Scotland, LPS levels $<0.1 \mathrm{ng} / \mathrm{mL}$ ), $2 \mathrm{mM}$ L-glutamine, $1 \mathrm{mM}$ sodium pyruvate and $40 \mu \mathrm{g} / \mathrm{ml}$ gentamycin (Flow laboratories, Rockwell, MD) in a $5 \% \mathrm{CO}_{2}$ humidified atmosphere at $37^{\circ} \mathrm{C}$. Cells $\left(1-2 \times 10^{5} / \mathrm{mL}\right)$ were cultured in complete RPMI 1640 medium at $37^{\circ} \mathrm{C}$ in the absence or presence of various concentrations of compounds $\left(10^{-7}-10^{-4} \mathrm{M}\right)$. After various periods of incubation, cells were collected, washed twice, and living cells (with diameters ranging from 7 to $14 \mu \mathrm{m}$ ) were counted in a cell Coulter Counter ZM equipped with a Coultronic 256 channelizer (Coulter/Beckman). Maturation of cells toward the monocyte/macrophage or granulocytic pathway was determined according to the change in morphology assessed by staining cytocentrifuged cells (using a Shandon 3 Cytospin, Thermo Electron) with the Hemacolor kit from Merck and light microscope examination, and quantification of several phenotypic markers characteristic of cell maturation into macrophages (CD11b) or granulocytes (CD15, CD13, CD44) as assessed by flow cytometry analysis (see below).

\section{Flow cytometry analysis of cell differentiation, apoptosis and death}

Intact cells were immunostained with Abs directed against CD11b, CD13, CD15, CD44 as described (Bauvois et al 2002). Analysis was performed in a FACS flow cytometer analyzer (Coulter-Beckman, Luminy, France). Values are given as percentages of positive cells and antigen relative density per cell (obtained by subtracting the peak channel number of the negative control from the peak channel number of the corresponding experimental sample). Apoptosis was determined by the binding of Annexin-VFITC to phosphatidylserine exposed to the cell membrane, used in conjunction with propidium iodide (PI), to evaluate subpopulations of cells along the apoptotic pathway according to the manufacturer's instructions.

\section{Reverse transcriptase-polymerase chain reaction (RT-PCR)}

RNA extraction from treated cells and cDNA synthesis were conducted as described (Bauvois et al 2002). Specific human primers for human $\beta 2$-microglobulin, MMP9, TNF$\alpha$, and vascular endothelial growth factor (VEGF), chosen according to published sequences (Westphal et al 2000; Bauvois et al 2002; Stordeur et al 2002; Parks et al 2004) were as follows: $\beta 2$-microglobulin (165 bp), 5'-CAT CCA GCG TAC TCC AAA GA-3' (forward) and 5'-GAC AAGT CTG AAT GCT CCA C-3' (reverse); MMP-9 (296 bp), 5'- GGA
GAC CTG AGA ACC AAT CTC-3' (forward) and 5'-TCC AAT AGG TGA TGT TGT CGT-3' (reverse); VEGF (204 bp), 5'- ACA TCT TCC AGG AGT ACC CTG ATG AG-3' (forward) and 5' - GCA TTC ACA TTT GTT GTG CTG T-3' (reverse); TNF- $\alpha$ (406 bp), 5'-ACC ATG AGC ACT GAA AGC AT-3' (forward) and 5'-AGA TGA GGT ACA GGC CCT CT-3' (reverse). The PCR products were visualized by electrophoresis in $2 \%$ agarose gel containing $0.2 \mu \mathrm{g} / \mathrm{ml}$ ethidium bromide. The $\beta 2$-microglobulin gene was used to normalize the PCR products. The NIH Image 1.63 software was used for the analysis of the bands after acquisition in an Appligen densitometer (Oncor).

\section{Measurement of MMP-9 gelatinolytic activity by zymography}

Analysis of MMP-9 activity was carried out in 7.5\% (w/v) SDS-polyacrylamide gels containing $0.2 \%$ gelatin $(\mathrm{w} / \mathrm{v})$ as described elsewhere (Bauvois et al 2002). Equal amounts of culture media $(20 \mu \mathrm{l})$ were applied to the gel in Laemmli sample buffer lacking $\beta$-mercaptoethanol. Gelatinolytic activities of pro-MMP-9 (92 kDa) and mature MMP-9 (82 kDa) were detected as transparent bands on the background of Eza-blue stained gelatin. The bands were acquired with an Appligen densitometer (Oncor).

\section{Enzyme-linked immunosorbent assays}

The culture supernatant fractions from cells $\left(10^{5}\right.$ cells $\left./ \mathrm{mL}\right)$ cultured for 3 days in the absence or presence of thiosulfinates were harvested under sterile conditions and frozen before MMP-9, VEGF, and TNF- $\alpha$ contents were determined using commercial ELISA kits provided by R\&D (Abingdon, UK). Controls included FCS-supplemented RPMI 1640 medium alone incubated under the same conditions. The concentrations were calculated after substraction of the control values. Detection level was $10 \mathrm{pg} / \mathrm{mL}$ for TNF- $\alpha$ and VEGF, and $1 \mathrm{ng} / \mathrm{mL}$ for MMP-9.

\section{Statistical analysis}

Values are represented as means $\pm \mathrm{SD}$ of $\mathrm{n}$ independent experiments.

\section{Results \\ Pr2TS and Me2TS induce growth arrest of AML cell lines}

The antiproliferative potential of $\mathrm{All}_{2} \mathrm{TS}, \mathrm{Pr}_{2} \mathrm{TS}$ and $\mathrm{Me}_{2} \mathrm{TS}$ and their related sulfides (DADS, DAS, DMDS, DPDS) were first evaluated in the U937 cell line. Cells were cultured 3 days 
in the absence or in the presence of increasing concentrations of the compounds $\left(10^{-7}-10^{-3} \mathrm{M}\right)$. The growth of U937 cells was inhibited by $\mathrm{Pr}_{2} \mathrm{TS}$ (Figure 2A) and $\mathrm{Me}_{2} \mathrm{TS}$ (Figure 2B) with $\mathrm{IC}_{50}$ values (half-maximal inhibitory concentrations) of $2 \mu \mathrm{M}$, whereas their related sulfides in the same range of concentration did not alter cell growth (Figure $2 \mathrm{C}$ ). $\mathrm{All}_{2} \mathrm{TS}$, DAS, and DADS did not affect cell growth (Figure 2D) and HPLC analysis showed that $\mathrm{All}_{2} \mathrm{TS}$ was totally degraded upon $24 \mathrm{~h}$ cell culture. Kinetic studies indicated also a timedependent inhibitory effect of $\operatorname{Pr}_{2}$ TS and $\mathrm{Me}_{2}$ TS on cell growth (Figure 3A). NB4 and MonoMac-6 cell lines were also sensitive to $\mathrm{Pr}_{2} \mathrm{TS}$ and $\mathrm{Me}_{2}$ TS (Figure 3B).

\section{Pr2TS and Me2TS do not induce U937 cell death}

We next questioned whether the inhibition of U937 cell growth by $\mathrm{Pr}_{2} \mathrm{TS}$ and $\mathrm{Me}_{2} \mathrm{TS}$ was associated with cytotoxicity. The criteria for cell death, measured by Cell Coulter analysis, was based on the number of necrotic cells with diameters $\leq 7 \mu \mathrm{m}$ (reflecting cell shrinkage), and Figure 2A and B shows that $\mathrm{Pr}_{2} \mathrm{TS}$ and $\mathrm{Me}_{2} \mathrm{TS}$ tested did not induce a marked cytotoxic effect. It was next investigated whether decreased growth was related to apoptosis. To this end, we analyzed the surface binding of Annexin V, known as an early marker of apoptosis (Martin et al 1995) with simultaneous PI staining for necrotic cells. Figure 4 shows a representative experiment in which U937 cells were cultured for 3 days in the absence or presence of $\operatorname{Pr}_{2} \mathrm{TS}, \mathrm{Me}_{2} \mathrm{TS}(5 \mu \mathrm{M})$ in comparison to the proapoptotic agent nigericin as a positive control. In contrast to untreated U937 cells (Figure 4A), cells treated with nigericin were strongly positive for Annexin V (L4=34\%, Figure 4B, apoptotic cells) and for both Annexin V and PI (L2 = 40\%, Figure 4B, secondary necrotic cells). U937 cells treated with $\mathrm{Pr}_{2} \mathrm{TS}$ or $\mathrm{Me}_{2} \mathrm{TS}$ were found weakly positive for Annexin $\mathrm{V}$ (L4 $\leq 14 \%$ ), and for both Annexin V and PI (L2 $\leq 11 \%$, Figure 4B and 4C). Moreover, using Apo 2.7 antibody which reacts with a mitochondrial protein exposed on cells undergoing apoptosis, we confirmed that $\mathrm{Pr}_{2} \mathrm{TS}$ and $\mathrm{Me}_{2} \mathrm{TS}$ did not induce U937 cell apoptosis (data not shown).

\section{Pr2TS and Me2TS induce differentiation of AML cells towards macrophages}

The capacity of U937 cells to undergo macrophage maturation was further measured by examining the
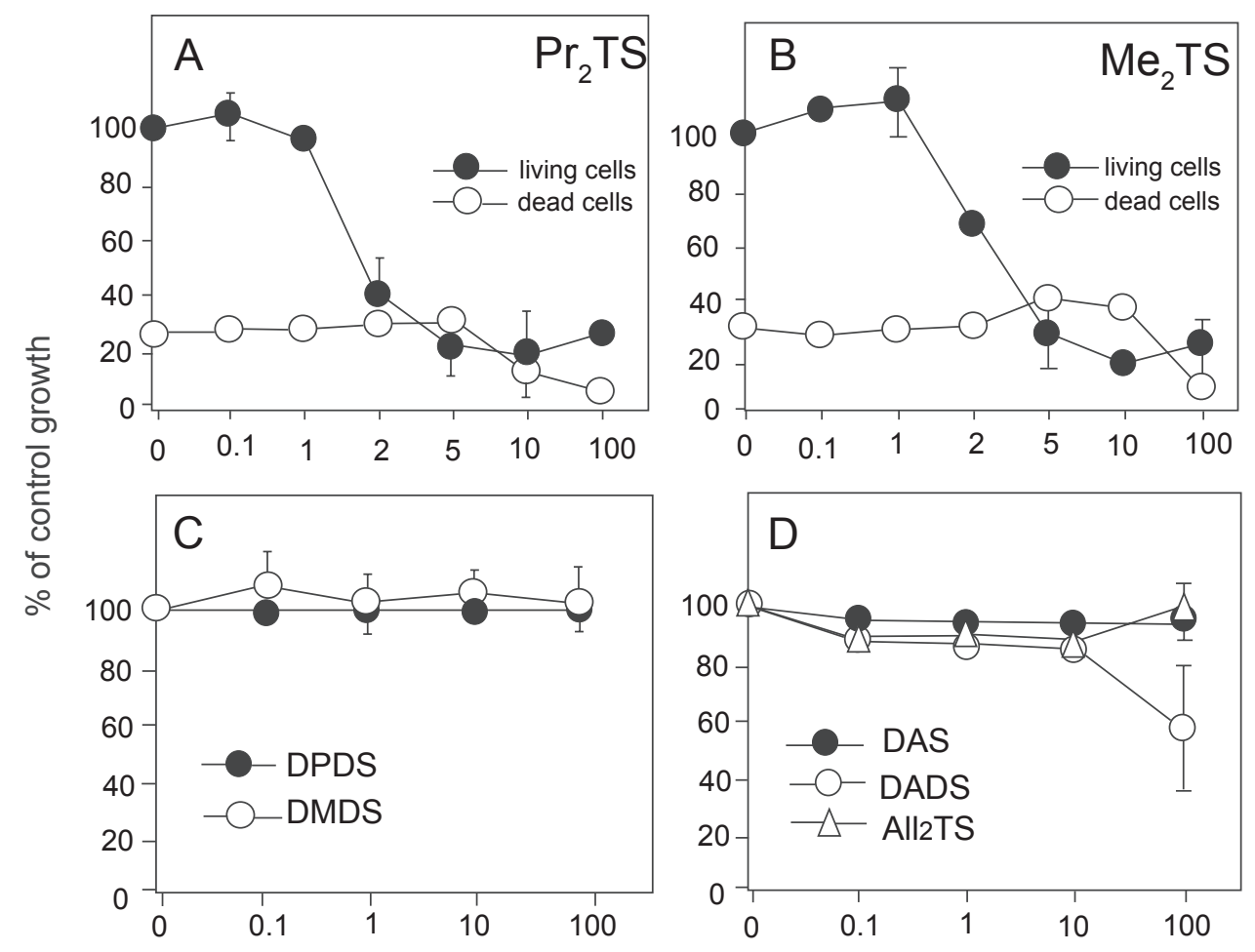

Compound concentration $(\mu \mathrm{M})$

Figure 2 Dose-dependent effects of thiosulfinates and sulfides on $\mathrm{U} 937$ cell proliferation. Cells ( $\left.10^{5} / \mathrm{mL}\right)$ were cultured for 3 days in the absence (control) or in the presence of increasing concentrations ( $\left.10^{-7}-10^{-4} \mathrm{M}\right)$ of $\operatorname{Pr}_{2} \mathrm{TS}(\mathbf{A}), \mathrm{Me}_{2} \mathrm{TS}(\mathbf{B})$, DPDS (C), DMDS (C), All $2 \mathrm{TS}$ (D), DAS (D) or DADS (D). After 3 days, living cells and necrotic cells were counted with a cell Coulter as described in Methods. Results are expressed as $\%$ of untreated cells $\left(100 \%=9 \times 10^{5}\right.$ cells $\left./ \mathrm{mL} \pm 10^{5}\right)$. Data represent the means of $2-5$ independent determinations \pm SD. 
A

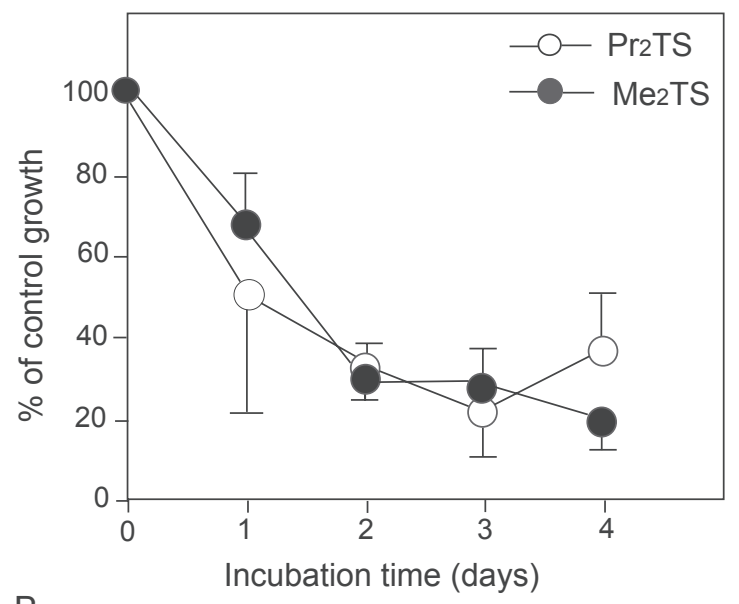

B

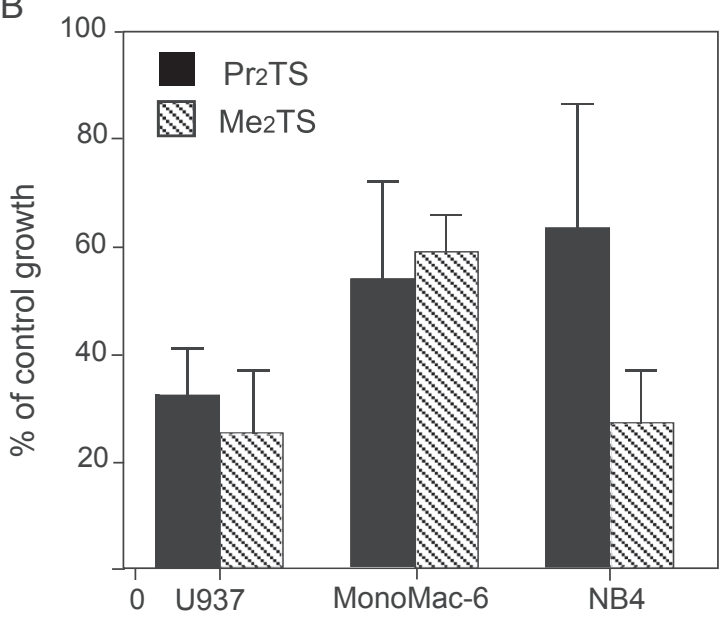

Figure 3 Time-dependent effects of $\mathrm{Pr}_{2} \mathrm{TS}$ and $\mathrm{Me}_{2} \mathrm{TS}$ on $\mathrm{U} 937$ cell proliferation; comparative effects with NB4 and MonoMac-6 cells. (A) U937 cells $\left(10^{5} / \mathrm{mL}\right)$ were cultured in the absence or presence of $5 \mu \mathrm{M} \mathrm{Pr}_{2} \mathrm{TS}$ or $\mathrm{Me}_{2} \mathrm{TS}$ for I to 4 days. Results are expressed as percentage of untreated cells $\left(100 \%=9 \times 10^{5}\right.$ cells $\left./ \mathrm{mL} \pm 10^{5}\right)$. Data represent the means of 2 to 6 independent determinations \pm SD. (B) U937, NB4 and MonoMac- 6 cells $\left(10^{5} / \mathrm{mL}\right)$ were cultured in the absence or presence of $5 \mu \mathrm{MPr}_{2} \mathrm{TS}$ or $\mathrm{Me}_{2}$ TS for 3 days (U937, NB4, MonoMac-6). Results are expressed as percentage of untreated cells. $\left(100 \%=9 \times 10^{5}\right.$ cells $/ \mathrm{mL} \pm 10^{5}$ for U937 and MonoMac-6; $100 \%=$ $8 \times 10^{5}$ cells $/ \mathrm{mL} \pm 10^{5}$ for NB4). Data represent the means of $n$ independent determinations \pm SD ( $n=7$ to 13 for U937; $n=5$ to 6 for MonoMac- $6 ; n=3$ to 6 for NB4).

modulation of expression of the CD11b antigen and the change in morphology of stimulated cells. Enhanced CD11b expression has been associated with monocyte/macrophage differentiation (Kim et al 1991). At day 4, the block in growth of $\mathrm{Pr}_{2}$ TS- and $\mathrm{Me}_{2}$ TS-treated U937 cells was correlated with a marked enhanced expression of $\mathrm{CD} 11 \mathrm{~b}$ as compared to untreated cells (Figure 5A). In parallel, a change in morphology (increase in cell size, decrease in the nuclear/cytoplasmic ratio and apparition of vacuolisation) consistent with macrophage differentiation was observed in cells exposed to $\mathrm{Pr}_{2} \mathrm{TS}$ and $\mathrm{Me}_{2} \mathrm{TS}$ when compared to untreated cells (Figure 5B). As positive control, PMA-treated cells presented morphological features of cell maturation and these modifications were accompanied by the up-regulation of CD11b (Figure 5A and B). Similarly, $\mathrm{Pr}_{2} \mathrm{TS}$ and $\mathrm{Me}_{2} \mathrm{TS}$ induced a marked shift towards a macrophage morphology associated with the enhanced expression of CD11b in the other cell lines (data not shown).

\section{Pr2TS and Me2TS do not induce differentiation of HL-60 and NB4 cells towards granulocytes}

Additionally, we investigated whether $\operatorname{Pr}_{2} \mathrm{TS}$ and $\mathrm{Me}_{2} \mathrm{TS}$ could also induce differentiation part of these cells towards granulocytes. Myeloblastic cell lines such as NB4 and HL-60 can be induced to differentiate into granulocyte-like cells by all-trans retinoic acid (ATRA) (Collins 1987; Khanna-Gupta et al 1994). Previously described changes in antigen expression by ATRA-treated cells include the increase of CD15 in HL-60 and NB4 cells (Lanotte et al 1991; Trayner et al 1998; Barber et al 2008) and the down-regulation of CD13 and CD44 in HL-60 cells (Trayner et al 1998; Barber et al 2008). Although to a lower degree, $\operatorname{Pr}_{2} \mathrm{TS}$ and $\mathrm{Me}_{2} \mathrm{TS}(5 \mu \mathrm{M})$ were capable of inhibiting HL-60 cell growth (40\% inhibition at day 5). Following treatment with $10 \mu \mathrm{M}$ ATRA for 5 days, HL-60 and NB4 cells presented morphologic features of granulocytes (data not shown) associated with the increased expression of CD15 (HL-60 and NB4) and the decreased expression of CD13 and CD44 (HL-60) (Table 1). In contrast, cells treated with $\mathrm{Pr}_{2} \mathrm{TS}$ or $\mathrm{Me}_{2} \mathrm{TS}(5 \mu \mathrm{M})$ did not have any effect on CD13, CD15 and CD44 expression (Table 1). Together, our results indicate that $\mathrm{Pr}_{2} \mathrm{TS}$ and $\mathrm{Me}_{2} \mathrm{TS}$ do not induce AML cells to mature along the granulocytic lineage.

\section{Inhibitory effects of Pr2TS and Me2TS on MMP- 9 and TNF- $\alpha$ release by $\mathrm{U} 937$ and NB4 cells}

As assessed by ELISA and zymography analyses of the conditioned media from day 3-cultured cells, very low amounts of matrix metalloproteinase-9 (MMP-9, $92 \mathrm{kDa}$ ) were produced by U937 cells and NB4 cells $(<10 \mathrm{ng} / \mathrm{mL})$. In parallel, no change in MMP-9 mRNA expression was observed to $\mathrm{Pr}_{2} \mathrm{TS}$ or $\mathrm{Me}_{2} \mathrm{TS}$ (from 24 to $72 \mathrm{~h}$, data not shown). As described previously (Watanabe et al 1993), exposure to PMA markedly increased the levels of released MMP-9 as assessed by its gelatinolytic activity (about 10-fold increase, Figure 6A). Addition of $\mathrm{Pr}_{2} \mathrm{TS}$ or $\mathrm{Me}_{2} \mathrm{TS}(5 \mu \mathrm{M})$ to the culture medium resulted in a reduction of released MMP-9 activity from PMA-activated cells (Figure 6A). ELISA data 


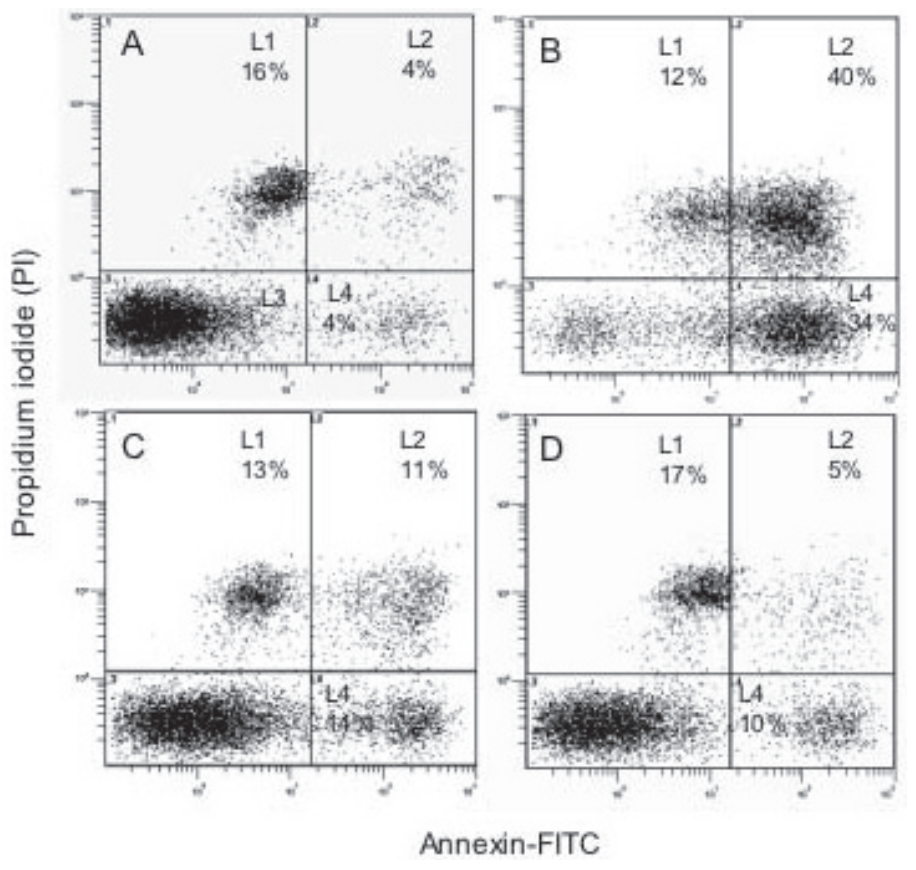

Figure 4 Representative histograms showing flow cytometry analysis of Annexin V-FITC/PI stained U937 cells. Cells were cultured in the absence (A) or presence of I0 $\mu$ M nigericin (proapoptotic agent, positive control) (B), $5 \mu \mathrm{M} \mathrm{Pr}_{2} \mathrm{TS}(\mathbf{C})$ or $5 \mu \mathrm{M} \mathrm{Me}_{2} \mathrm{TS}$ (D) on U937 cells for 3 days. Results are expressed as log PI fluorescence intensity (y-axis) vs $\log$ Annexin $V$ fluorescence intensity (x-axis).

Abbreviations: LI, necrotic cells; L2, secondary necrotic cells; L3, healthy cells; L4, apoptotic cells; PI, propidium iodide.
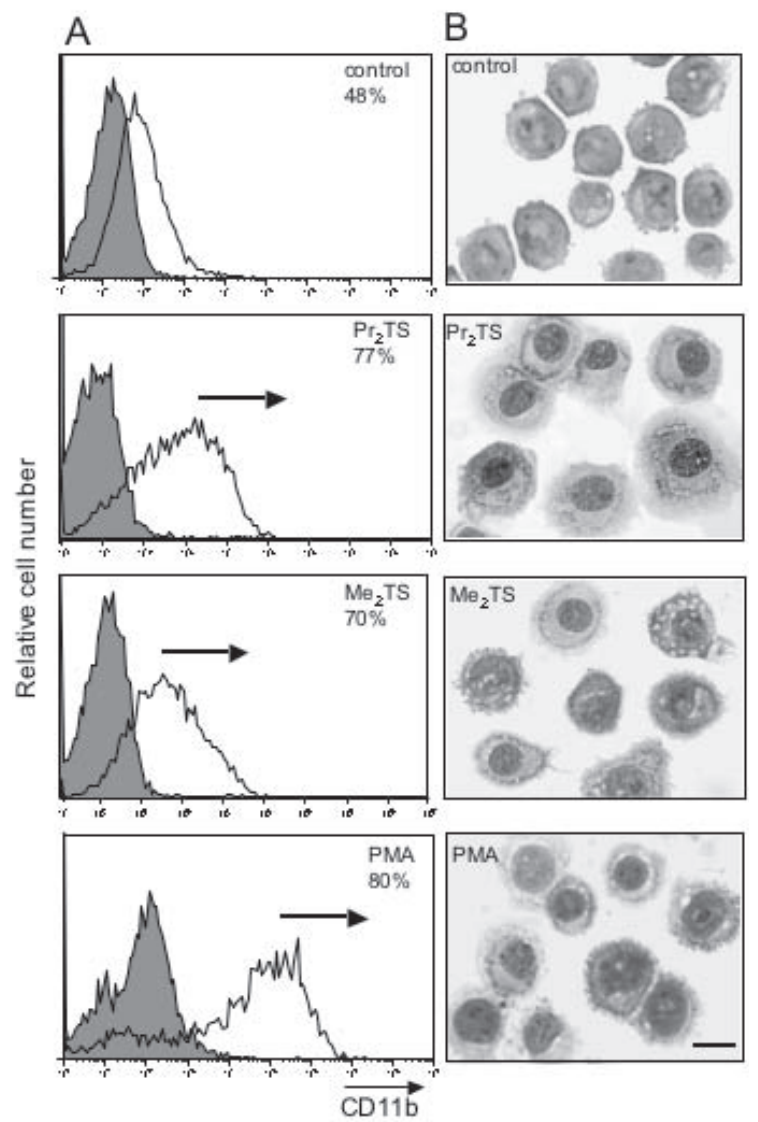

Figure 5 Differentiation effects of $\operatorname{Pr}_{2}$ TS and $\mathrm{Me}_{2}$ TS on $\mathrm{U} 937$ cells. Cells $\left(10^{5} / \mathrm{mL}\right)$ were cultured in the absence (control) or in the presence of $\mathrm{Pr}_{2} \mathrm{TS}, \mathrm{Me} \mathrm{TS}_{2}(5 \mu \mathrm{M})$ or $\mathrm{PMA}$ $(\mathrm{I} \mathrm{ng} / \mathrm{mL}$ ) for 4 days. (A) Specific fluorescence intensity of CDI lb antigen (black line) was detected by immunofluorescence in a Coulter flow cytometer as described in Methods. Staining of cells with a matched isotype antibody ( $\mathrm{mlgGI}$ ) served as the respective negative control (grey area). Results are expressed as relative cell number ( $y$-axis) vs log fluorescence intensity (x-axis).Values represent percentage of positive cells. One experiment representative of four different experiments is shown. (B) Light microscopic morphology of $U 937$ cells Original magnification x 600. May Grünwald stain. Scale bar, $10 \mu \mathrm{m}$. 
Table I Effects of ATRA, $\mathrm{Pr}_{2}$ TS and Me $\mathrm{MS}_{2}$ on the expression of CDI3, CDI5 and CD44 on HL-60 and NB4 cells

\begin{tabular}{|c|c|c|c|c|c|}
\hline \multirow[t]{2}{*}{ Antibody antigen } & \multirow{2}{*}{$\begin{array}{l}\text { Granulocyte } \\
\text { expression }\end{array}$} & \multicolumn{4}{|c|}{ Percent of positive cells (relative density) } \\
\hline & & Control & ATRA & $\mathrm{Pr}_{2} \mathrm{TS}$ & $\mathrm{Me}_{2} \mathrm{TS}$ \\
\hline \multicolumn{6}{|l|}{ I) on $\mathrm{HL}-60$} \\
\hline CDI3 & $\downarrow$ & $82(30)$ & $74(17)$ & $89(36)$ & $87(36)$ \\
\hline CDI5 & $\uparrow$ & $67(35)$ & $69(84)$ & $62(40)$ & $62(27)$ \\
\hline CD44 & $\downarrow$ & $48(168)$ & $42(28)$ & $47(169)$ & $48(197)$ \\
\hline \multicolumn{6}{|l|}{ 2) on NB4 } \\
\hline CDI5 & $\uparrow$ & $55(17)$ & $82(98)$ & $58(26)$ & $39(16)$ \\
\hline
\end{tabular}

Notes: Cells cultured for 5 days in the absence (control) or presence of ATRA (I0 $\mu$ M), $\operatorname{Pr}_{2}$ TS or Me $\mathrm{MS}_{2}(5 \mu \mathrm{M})$ were assayed for expression of surface CDI3, CDI 5 and CD44. Values are given as \% of CD positive cells and CD relative density per cell (in brackets), up-regulation of CDI5 (Lanotte et al I99I; Trayner et al I998; Barber et al 2008); down-regulation of CDI3 and CD44 (Trayner et al 1998; Barber et al 2008).

confirmed that diminished MMP-9 gelatinolytic activity resulted from the decrease in MMP-9 protein (Figure 6B). PCR analysis was used to examine the steady-state MMP-9 mRNA alteration before and after $\mathrm{Pr}_{2} \mathrm{TS}$ or $\mathrm{Me}_{2} \mathrm{TS}$ treatment. As shown in Figure 6C, $\operatorname{Pr}_{2} \mathrm{TS}$ or $\mathrm{Me}_{2} \mathrm{TS}$ did not alter the apparent levels of MMP-9 transcripts in PMA-activated cells treated for $24 \mathrm{~h}$. In parallel, the amounts of TNF- $\alpha$ protein released from PMA-activated cells were also strongly diminished following $\mathrm{Pr}_{2} \mathrm{TS}$ or $\mathrm{Me}_{2} \mathrm{TS}$ treatment (Figure 7A) while the mRNA contents of TNF- $\alpha$ were slightly affected by $\mathrm{Pr}_{2} \mathrm{TS}$ or $\mathrm{Me}_{2} \mathrm{TS}$ at $24 \mathrm{~h}$ (Figure 7B), TNF- $\alpha$ mRNA/ $\beta 2$ mRNA ratios being decreased by $25 \%$ for $\operatorname{Pr}_{2}$ TS and $49 \%$ for $\mathrm{Me}_{2} \mathrm{TS}$. In both cell types, vascular endothelial growth factor (VEGF) protein and mRNA levels remained almost unchanged by $\operatorname{Pr}_{2}$ TS and $\mathrm{Me}_{2} \mathrm{TS}$ (Figure 7A and B).

\section{Discussion}

Our present study provides new information about the influence of thiosulfinates (TS) in human malignant myeloid cell lines which are representative of acute myeloid leukemia cells accordingly to the French-American-British (FAB) classification. These are HL-60 (FAB M2), NB4 (FAB M3), U937 and MonoMac-6 (FAB M5) cell lines.

We first describe the ability of $\mathrm{Pr}_{2} \mathrm{TS}$ and $\mathrm{Me}_{2} \mathrm{TS}$ to inhibit in a concentration- and time-dependent manner the growth of leukemic cells in vitro. The comparison with their sulfide analogues (DPDS and DMDS) which do not show any influence on cell proliferation in the same range of concentration (up to $100 \mu \mathrm{M}$ ), suggests that the sulfoxide group plays a critical role in TS activity. In contrast, $\mathrm{All}_{2} \mathrm{TS}$ as well as its sulfide analogues DAS and DADS did not affect cell growth, and such lack of effect of $\mathrm{All}_{2}$ TS was associated to its decomposition to sulfides as previously reported (Amagase 2006). In contrast to our study, allyl sulfides (from 10 to $100 \mu \mathrm{M}$ ) have been reported to reduce in culture and in vivo the growth rate of human cancer cell lines derived from solid tumors (Sundaram et al 1996b; Hosono et al 2005; Xiao et al 2005, 2006; Milner 2006), possibly by regulating factors involved in cellular proliferation such as NF-אB (Pinto et al 2001) or p21 (Milner 2006). Further research is required to clarify the mechanisms of inhibition of AML cell proliferation by $\mathrm{Pr}_{2} \mathrm{TS}$ and $\mathrm{Me}_{2} \mathrm{TS}$. The mitogen-activated protein kinase (MAPK) pathway that proceeds from Ras, and its downstream effector Raf to MAPK kinase (MEK) and extracellular signal activated kinase (ERK), links various extracellular stimuli to proliferation, differentiation and survival. The MAPK signaling is constitutively active in blast cells of the majority of AML patients, and its blockade by selective small molecules inhibitors impairs leukemic cell proliferation (Milella et al 2001; Platanias 2003). It has also to be pointed out that the level of NF- $\mathrm{KB}$ is high in AML (Baumgartner et al 2002). Whether $\mathrm{Pr}_{2} \mathrm{TS}$ and $\mathrm{Me}_{2}$ TS block NF- $\kappa \mathrm{B}$ or MAPK activities is currently under investigation.

Organosulfur compounds may exhibit proapoptotic actions on various models of human cancers (Sundaram et al 1996a; Kwon et al 2002; Xiao et al 2003, 2005; Herman-Antosiewicz et al 2004; Hosono et al 2005). However, our experiments clearly indicate that $\operatorname{Pr}_{2} \mathrm{TS}$ and $\mathrm{Me}_{2} \mathrm{TS}$ do not induce cell apoptosis. Instead, the block in AML cell growth by $\mathrm{Pr}_{2} \mathrm{TS}$ and $\mathrm{Me}_{2} \mathrm{TS}$ is accompanied by differentiation of cells toward the monocyte/macrophage pathway as assessed by phenotypic and morphologic features. TNF- $\alpha$ is an autocrine stimulus for supporting macrophage differentiation (De Benedetti et al 1990; Kamijo et al 1990). By ELISA analysis, we showed that unstimulated cells secreted very low levels of TNF- $\alpha\left(2 \pm 0.17 \mathrm{pg} / \mathrm{mL} / 10^{5}\right.$ cells $)$ which were not altered with $\operatorname{Pr}_{2} \mathrm{TS}\left(1.81 \pm 0.17 \mathrm{pg} / \mathrm{mL} / 10^{5}\right.$ cells $)$ 


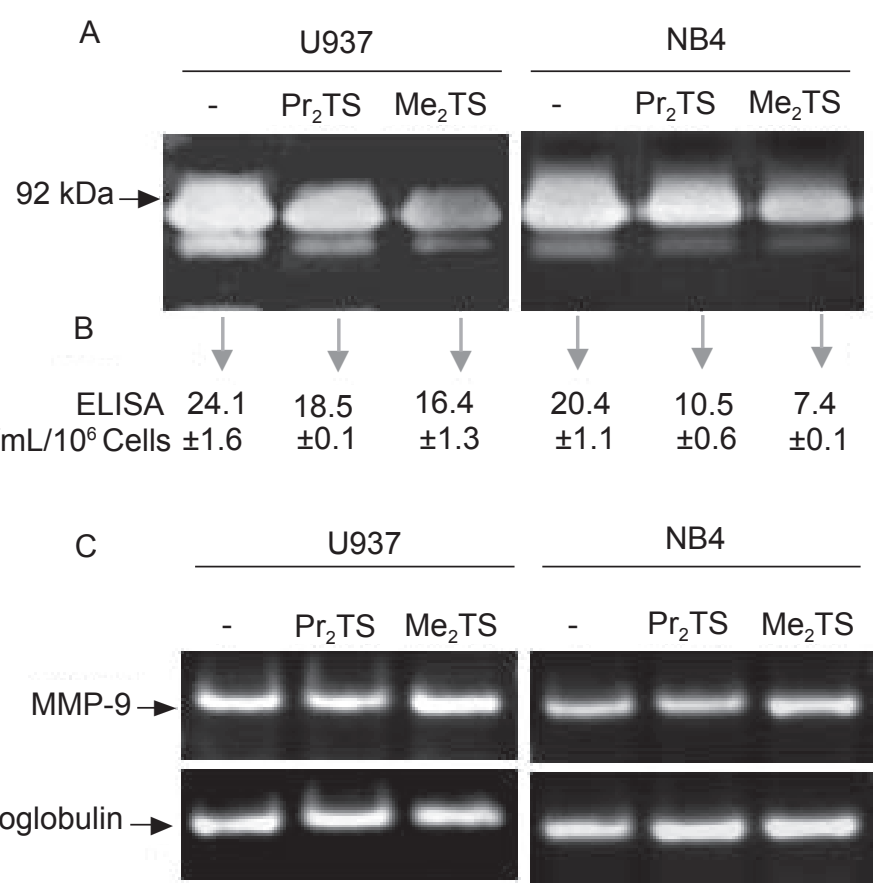

Figure 6 Effects of $\mathrm{Pr}_{2}$ TS and Me $\mathrm{e}_{2}$ TS on MMP-9 expression in PMA-activated U937 and NB4 cells. U937 and NB4 cells ( $\left.10^{5} / \mathrm{mL}\right)$ activated with I ng/mL PMA, were cultured for 24 or $72 \mathrm{~h}$ in the absence or presence of $\operatorname{Pr}_{2} \mathrm{TS}$ and $\mathrm{Me}_{2} \mathrm{TS}(5 \mu \mathrm{M})$. (A) Analysis of gelatinolytic activity in the culture media of $72 \mathrm{~h}$-treated cells. The enzymatic activity of MMP-9 was analyzed using zymography performed with equal amounts of protein loaded. Gelatinolytic activities are detected as clear bands in the gel. (B) MMP-9 concentrations in the culture media of $72 \mathrm{~h}$-treated cells were quantified by ELISA.Values are expressed as $\mathrm{ng} / \mathrm{mL} / 10^{5}$ cells (mean of 2 determinations \pm SD). (C) RT-PCR analysis of MMP-9 and $\beta 2$-microglobulin transcripts in $24 \mathrm{~h}$-treated cells.

A
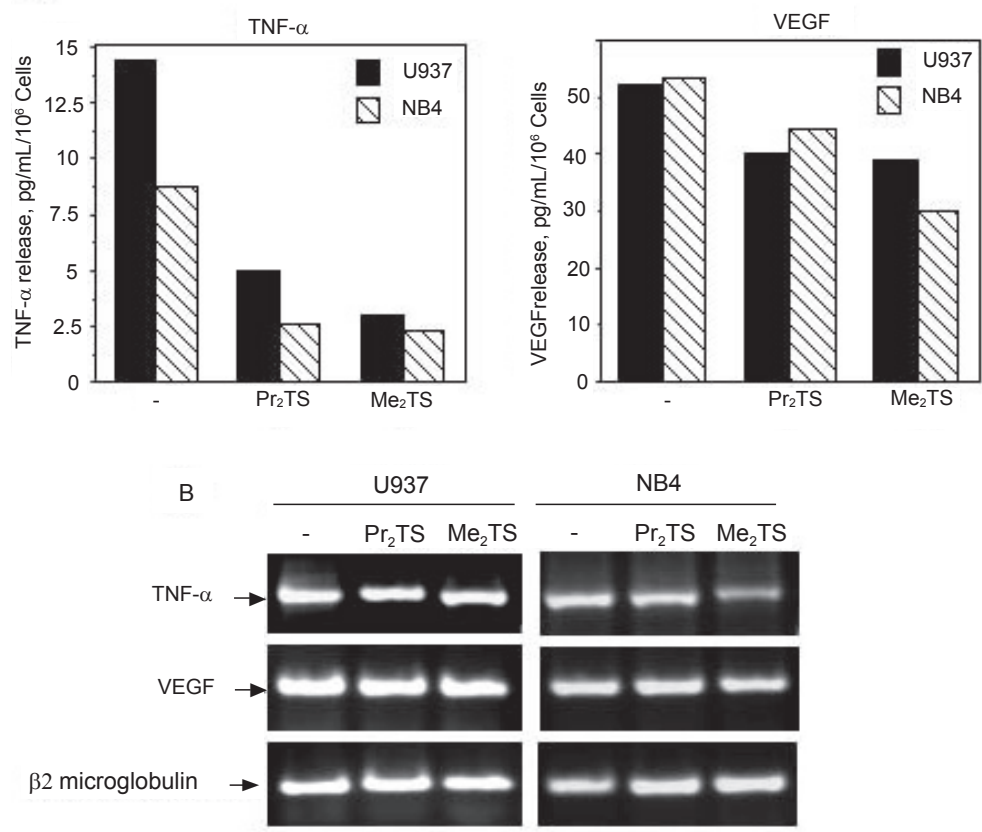

Figure 7 Effects of $\operatorname{Pr}_{2}$ TS and Me 2 TS on VEGF and TNF- $\alpha$ expression in PMA-activated U937 and NB4 cells. U937 and NB4 cells (I05/mL) activated with I ng/mL PMA, were cultured for 24 or $72 \mathrm{~h}$ in the absence or presence of $\operatorname{Pr}_{2}$ TS and $\mathrm{Me}_{2} \mathrm{TS}(5 \mu \mathrm{M})$. (A) ELISA analyses of VEGF and TNF- $\alpha$ concentrations in culture media of $72 \mathrm{~h}$-treated cells. Values are expressed as $\mathrm{pg} / \mathrm{mL} / 10^{5}$ cells. (B) RT-PCR analysis of VEGF,TNF- $\alpha$ and $\beta 2$-microglobulin transcripts in 24 h-treated cells. 
or $\mathrm{Me}_{2} \mathrm{TS}\left(1.94 \pm 0.19 \mathrm{pg} / \mathrm{mL} / 10^{5}\right.$ cells $)$ thus indicating that endogenous TNF- $\alpha$ is not implicated in $\mathrm{Pr}_{2} \mathrm{TS}-/$ $\mathrm{Me}_{2}$ TS-mediated cell maturation. The molecular mechanisms involved in regulating the balance between proliferation and differentiation in the monocytic/macrophage lineage remain poorly understood. The retinoblastoma gene product (Bergh et al 1999), interferon regulatory factors (Manzella et al 1999; Lu et al 2001) and the Ets repressor PE-1/METS (Sawka-Verhelle et al 2004) have been reported to play a critical role in the monocytic commitment. Whether $\operatorname{Pr}_{2} \mathrm{TS}$ and $\mathrm{Me}_{2} \mathrm{TS}$ could influence the activity of these factors remains to be determined. Differentiation therapy with retinoic acid plays an important role in treating acute promyelocytic leukemia (Jurcic et al 2007). Our data suggests that the addition of specific agents such as $\operatorname{Pr}_{2} \mathrm{TS}$ or $\mathrm{Me}_{2} \mathrm{TS}$ to differentiation therapy could be explored.

AML is an hematological disorder which is associated with an increased angiogenesis which disappears if complete hematological remission is achieved (Rajkumar et al 2002; Ribatti et al 2004; Longo et al 2007). Because of its capacities to degrade components of the extracellular matrix and angiogenic factors, MMP-9 can play a role in cancer progression by affecting tumor angiogenesis, tumor growth and/or metastasis (Opdenakker et al 2003; Parks et al 2004; Deryugina et al 2006). MMP-9 is synthesized as a preproenzyme, secreted as a proform $(92 \mathrm{kDa})$ and processed in a $82 \mathrm{kDa}$ form resulting from the proteolytic removal of a fragment of its N-terminal domain (Opdenakker et al 2003). AML leukemic cells express and release $92 \mathrm{kDa}$ MMP-9 (Klein et al 2004). We show here that $\operatorname{Pr}_{2} \mathrm{TS}$ and $\mathrm{Me}_{2} \mathrm{TS}$ decrease MMP-9 production by activated U937 and NB4 cells. At the mRNA level, no early regulation was detectable indicating a post-transcriptional event. In connection with organosulfurs, Meyer and colleagues (2004) showed that DADS inhibit the secretion of MMP-9 by HUVEC cells while not affecting MMP-9 mRNA levels. Besides MMP-9, VEGF and TNF- $\alpha$ are important partners of angiogenesis (Kini et al 2001; Thomas et al 2001; Ribatti et al 2004). In addition to its angiogenic properties, VEGF may serve as an autocrine/paracrine growth factor for leukemia cells (Fiedler et al 1997; Rajkumar et al 2002). TNF- $\alpha$ stimulates various NF- $\mathrm{KB}$ target genes that modulate cell survival and proliferation, tumor metastasis and angiogenesis (Braun et al 2006; Cilloni et al 2007). Among NF- $\kappa B$ target genes are MMP-9 and Bcl-2 whose proteins levels are enhanced in AML (Mayo et al 2000; Braun et al 2006). A previous study showed that DADS inhibited the production of IL-1 $\beta$ and TNF- $\alpha$ by blood monocytes stimulated with lipopolysaccharide (Keiss et al 2003). Our results indicate that $\mathrm{Pr}_{2} \mathrm{TS}$ and $\mathrm{Me}_{2}$ TS inhibit TNF- $\alpha$ production by U937 and NB4 cells at the post-transcriptional level, without affecting VEGF expression. Whether $\operatorname{Pr}_{2}$ TS and $\mathrm{Me}_{2} \mathrm{TS}$ inhibit the synthesis or the release of MMP- 9 and TNF- $\alpha$ remains to be determined.

In conclusion, this work provides first evidence that $\mathrm{Pr}_{2}$ TS and $\mathrm{Me}_{2}$ TS may exhibit antitumor activity against AML cell lines by affecting cell growth, differentiation and secretion of factors involved in tumoral processes. Our data suggest that these TS are promising compounds for improving AML therapy. A very recent study has demonstrated selective apoptosis of childhood pre-B acute lymphoblastic leukemia cells in vitro by DATS and ajoene (Hodge et al 2008) emphasizing the potential of Allium for possible treatment of human leukemias. Further studies are required to validate our observations with these TS in AML patients' cells.

\section{Acknowledgments}

The authors thank Dr M Lanotte (Hôpital Saint Louis, Paris, France) for supplying NB4 cell line, Dr HW Ziegler-Heitbrock (University of Munich, Germany) for supplying MonoMac-6 cell line, and Ares-Serono (Geneva, Switzerland) for all-trans retinoic acid. This work was supported by grants from the Délégation Générale pour l’Armement (grant N ${ }^{\circ} 20214$ ), the Association pour la Recherche sur le Cancer (grant N ${ }^{\circ 3473)}$ and the Ligue Nationale Française contre le Cancer (Comité de Paris, grant $\mathrm{N}^{\circ} \mathrm{RS}$ 07/75-55).

\section{References}

Ackermann RT, Mulrow CD, Ramirez G, et al. 2001. Garlic shows promise for improving some cardiovascular risk factors. Arch Intern Med, 161:813-24.

Adachi S, Leoni LM, Carson DA, et al. 2004. Apoptosis induced by molecular targeting therapy in hematological malignancies. Acta Haematol, 111:107-23.

Amagase H. 2006. Clarifying the real bioactive constituents of garlic. JNutr, 136:716S-25S.

Arnault I, Christides JP, Mandon N, et al. 2003. High-performance ion-pair chromatography method for simultaneous analysis of alliin, deoxyalliin, allicin and dipeptide precursors in garlic products using multiple mass spectrometry and UV detection. J Chromatogr A, 991:69-75.

Auger J, Lalau-Keraly F, Belinsky C. 1990. Thiosulfinates in vapor phase are stable and they can persist in the environment of allium. Chemosphr, 21:837-43.

Badol P, David-Dufilho M, Auger J, et al. 2007. Thiosulfinates modulate platelet activation by reaction with surface free sulfhydryls and internal thiol-containing proteins. Platelets, 18:481-90.

Barber N, Belov L, Christopherson RI. 2008. All-trans retinoic acid induces different immunophenotypic changes on human HL60 and NB4 myeloid leukaemias. Leuk Res, 32:315-22.

Baumgartner B, Weber M, Quirling M, et al. 2002. Increased IkappaB kinase activity is associated with activated NF-kappaB in acute myeloid blasts. Leukemia, 16:2062-71. 
Bauvois B, Dumont J, Mathiot C, et al. 2002. Production of matrix metalloproteinase-9 in early stage B-CLL: suppression by interferons. Leukemia, 16:791-8.

Bergh G, Ehinger M, Olsson I, et al. 1999. Involvement of the retinoblastoma protein in monocytic and neutrophilic lineage commitment of human bone marrow progenitor cells. Blood, 94:1971-8.

Borek C. 2006. Garlic reduces dementia and heart-disease risk. J Nutr, 136:810S-2S.

Braun T, Carvalho G, Fabre C, et al. 2006. Targeting NF-kappaB in hematologic malignancies. Cell Death Differ, 13:748-58.

Cilloni D, Martinelli G, Messa F, et al. 2007. Nuclear factor kB as a target for new drug development in myeloid malignancies. Haematologica, 92:1224-9.

Collins SJ. 1987. The HL-60 promyelocytic leukemia cell line: proliferation, differentiation, and cellular oncogene expression. Blood, 70:1233-44.

De Benedetti F, Falk LA, Ellingsworth LR, et al. 1990. Synergy between transforming growth factor-beta and tumor necrosis factor-alpha in the induction of monocytic differentiation of human leukemic cell lines. Blood, 75:626-32.

Deryugina EI, Quigley JP. 2006. Matrix metalloproteinases and tumor metastasis. Cancer Metastasis Rev, 25:9-34.

Drexler HG, Matsuo Y. 1999. Guidelines for the characterization and publication of human malignant hematopoietic cell lines. Leukemia, 13:835-42.

Drexler HG, Quentmeier H, MacLeod RA. 2004. Malignant hematopoietic cell lines: in vitro models for the study of MLL gene alterations. Leukemia, 18:227-32.

Ferrara FF, Fazi F, Bianchini A, et al. 2001. Histone deacetylase-targeted treatment restores retinoic acid signaling and differentiation in acute myeloid leukemia. Cancer Res, 61:2-7.

Fiedler W, Graeven U, Ergun S, et al. 1997. Vascular endothelial growth factor, a possible paracrine growth factor in human acute myeloid leukemia. Blood, 89:1870-5.

Herman-Antosiewicz A, Singh SV. 2004. Signal transduction pathways leading to cell cycle arrest and apoptosis induction in cancer cells by Allium vegetable-derived organosulfur compounds: a review. Mutat Res, 555:121-31.

Hodge G, Davis S, Rice M, et al. 2008. Garlic compounds selectively kill childhood pre-B acute lymphoblastic leukemia cells in vitro without reducing T-cell function: Potential therapeutic use in the treatment of ALL. Biologics Targets and Therapy, 1:143-9.

Hosono T, Fukao T, Ogihara J, et al. 2005. Diallyl trisulfide suppresses the proliferation and induces apoptosis of human colon cancer cells through oxidative modification of beta-tubulin. J Biol Chem, 280:41487-93.

Ippoushi K, Itou H, Azuma K, et al. 2002. Effect of naturally occurring organosulfur compounds on nitric oxide production in lipopolysaccharide-activated macrophages. Life Sci, 71:411-19.

Jurcic JG, Soignet SL, Maslak AP. 2007. Diagnosis and treatment of acute promyelocytic leukemia. Curr Oncol Rep, 9:337-44.

Kamijo R, Takeda K, Nagumo M, et al. 1990. Effects of combinations of transforming growth factor-beta 1 and tumor necrosis factor on induction of differentiation of human myelogenous leukemic cell lines. J Immunol, 144:1311-16.

Keiss HP, Dirsch VM, Hartung T, et al. 2003. Garlic (Allium sativum L.) modulates cytokine expression in lipopolysaccharide-activated human blood thereby inhibiting NF-kappaB activity. J Nutr, 133:2171-5.

Khanna-Gupta A, Kolibaba K, Zibello TA, et al. 1994. NB4 cells show bilineage potential and an aberrant pattern of neutrophil secondary granule protein gene expression. Blood, 84:294-302.

Khanum F, Anilakumar KR, Viswanathan KR. 2004. Anticarcinogenic properties of garlic: a review. Crit Rev Food Sci Nutr, 44:479-88.

Kim YR, Abraham NG, Lutton JD. 1991. Mechanisms of differentiation of U937 leukemic cells induced by GM-CSF and 1,25(OH)2 vitamin D3. Leuk Res, 15:409-18.

King ME, Rowe JM. 2007. Recent developments in acute myelogenous leukemia therapy. Oncologist, 12(Suppl 2):14-21.
Kini AR, Peterson LA, Tallman MS, et al. 2001. Angiogenesis in acute promyelocytic leukemia: induction by vascular endothelial growth factor and inhibition by all-trans retinoic acid. Blood, 97:3919-24.

Klein G, Vellenga E, Fraaije MW, et al. 2004. The possible role of matrix metalloproteinase (MMP)-2 and MMP-9 in cancer, eg, acute leukemia. Crit Rev Oncol Hematol, 50:87-100.

Kwon KB, Yoo SJ, Ryu DG, et al. 2002. Induction of apoptosis by diallyl disulfide through activation of caspase-3 in human leukemia HL-60 cells. Biochem Pharmacol, 63:41-7.

Lanotte M, Martin-Thouvenin V, Najman S, et al. 1991. NB4, a maturation inducible cell line with $\mathrm{t}(15 ; 17)$ marker isolated from a human acute promyelocytic leukemia (M3). Blood, 77:1080-6.

Lanzotti V. 2006. The analysis of onion and garlic. J Chromatogr A, 1112:3-22.

Le Bon AM, Siess MH. 2000. Organosulfur compounds from Allium and the chemoprevention of cancer. Drug Metabol Drug Interact, 17:51-79.

Leone G, Sica S, Voso MT, et al. 2006. Treatment of acute leukaemias with monoclonal antibodies: current status and future prospects. Cardiovasc Hematol Agents Med Chem, 4:33-52.

Longo V, Vacca A, Ribatti D. 2007. Imaging and angiogenesis in hematological malignancies. Leukemia, 21:1605.

Lu R, Pitha PM. 2001. Monocyte differentiation to macrophage requires interferon regulatory factor 7. J Biol Chem, 276:45491-6.

Manzella L, Conte E, Cocchiaro G, et al. 1999. Role of interferon regulatory factor 1 in monocyte/macrophage differentiation. Eur J Immunol, 29:3009-16.

Martin SJ, Reutelingsperger CP, McGahon AJ, et al. 1995. Early redistribution of plasma membrane phosphatidylserine is a general feature of apoptosis regardless of the initiating stimulus: inhibition by overexpression of Bcl-2 and Abl. J Exp Med, 182:1545-56.

Mason KD, Juneja SK, Szer J. 2006. The immunophenotype of acute myeloid leukemia: is there a relationship with prognosis? Blood Rev, 20:71-82.

Mayo MW, Baldwin AS. 2000. The transcription factor NF-kappaB: control of oncogenesis and cancer therapy resistance. Biochim Biophys Acta, 1470:M55-62.

Meyer K, Ueberham E, Gebhardt R. 2004. Influence of organosulphur compounds from garlic on the secretion of matrix metalloproteinases and their inhibitor TIMP-1 by cultured HUVEC cells. Cell Biol Toxicol, 20:253-60.

Milella M, Kornblau SM, Estrov Z, et al. 2001. Therapeutic targeting of the MEK/MAPK signal transduction module in acute myeloid leukemia. $J$ Clin Invest, 108:851-9.

Milner JA. 2006. Preclinical perspectives on garlic and cancer. J Nutr, 136:827S-31S.

Opdenakker G, Nelissen I, Van Damme J. 2003. Functional roles and therapeutic targeting of gelatinase B and chemokines in multiple sclerosis. Lancet Neurol, 2:747-56.

Parks WC, Wilson CL, Lopez-Boado YS. 2004. Matrix metalloproteinases as modulators of inflammation and innate immunity. Nat Rev Immunol, 4:617-29.

Pinto JT, Rivlin RS. 2001. Antiproliferative effects of allium derivatives from garlic. J Nutr, 131:1058S-60S.

Platanias LC. 2003. Map kinase signaling pathways and hematologic malignancies. Blood, 101:4667-79.

Plesa C, Chelghoum Y, Plesa A, et al. 2008. Prognostic value of immunophenotyping in elderly patients with acute myeloid leukemia: a singleinstitution experience. Cancer, 112:572-80.

Qi R, Liao F, Inoue K, et al. 2000. Inhibition by diallyl trisulfide, a garlic component, of intracellular $\mathrm{Ca}(2+)$ mobilization without affecting inositol-1,4, 5-trisphosphate (IP(3)) formation in activated platelets. Biochem Pharmacol, 60:1475-83.

Rajkumar SV, Mesa RA, Tefferi A. 2002. A review of angiogenesis and anti-angiogenic therapy in hematologic malignancies. $J$ Hematother Stem Cell Res, 11:33-47. 
Rendu F, Brohard-Bohn B, Pain S, et al. 2001. Thiosulfinates inhibit platelet aggregation and microparticle shedding at a calpain-dependent step. Thromb Haemost, 86:1284-91.

Ribatti D, Scavelli C, Roccaro AM, et al. 2004. Hematopoietic cancer and angiogenesis. Stem Cells Dev, 13:484-95.

Sawka-Verhelle D, Escoubet-Lozach L, Fong AL, et al. 2004. PE-1/METS, an antiproliferative Ets repressor factor, is induced by CREB-1/CREM-1 during macrophage differentiation. $J$ Biol Chem, 279:17772-84.

Stordeur P, Poulin LF, Craciun L, et al. 2002. Cytokine mRNA quantification by real-time PCR. J Immunol Methods, 259:55-64.

Sundaram SG, Milner JA. 1996a. Diallyl disulfide induces apoptosis of human colon tumor cells. Carcinogenesis, 17:669-73.

Sundaram SG, Milner JA. 1996b. Diallyl disulfide inhibits the proliferation of human tumor cells in culture. Biochim Biophys Acta, 1315:15-20.

Thomas DA, Giles FJ, Cortes J, et al. 2001. Antiangiogenic therapy in leukemia. Acta Haematol, 106:190-207.

Thomas X, Elhamri M. 2007. Tipifarnib in the treatment of acute myeloid leukemia. Biologics: Targets and Therapy, 1:415-24.

Trayner ID, Bustorff T, Etches AE, et al. 1998. Changes in antigen expression on differentiating HL60 cells treated with dimethylsulphoxide, all-trans retinoic acid, alpha1, 25-dihydroxyvitamin D3 or 12-O-tetradecanoyl phorbol-13-acetate. Leuk Res, 22:537-47.
Watanabe H, Nakanishi I, Yamashita K, et al. 1993. Matrix metalloproteinase-9 (92 kDa gelatinase/type IV collagenase) from U937 monoblastoid cells: correlation with cellular invasion. $J$ Cell Sci, 104(Pt 4):991-9.

Westphal JR, Van't Hullenaar R, Peek R, et al. 2000. Angiogenic balance in human melanoma: expression of VEGF, bFGF, IL-8, PDGF and angiostatin in relation to vascular density of xenografts in vivo. Int J Cancer, 86:768-76.

Xiao D, Pinto JT, Gundersen GG, et al. 2005. Effects of a series of organosulfur compounds on mitotic arrest and induction of apoptosis in colon cancer cells. Mol Cancer Ther, 4:1388-98.

Xiao D, Pinto JT, Soh JW, et al. 2003. Induction of apoptosis by the garlic-derived compound S-allylmercaptocysteine (SAMC) is associated with microtubule depolymerization and c-Jun NH(2)-terminal kinase 1 activation. Cancer Res, 63:6825-37.

Xiao D, Singh SV. 2006. Diallyl trisulfide, a constituent of processed garlic, inactivates Akt to trigger mitochondrial translocation of BAD and caspase-mediated apoptosis in human prostate cancer cells. Carcinogenesis, 27:533-40.

Zheng S, Yang H, Zhang S, et al. 1997. Initial study on naturally occurring products from traditional Chinese herbs and vegetables for chemoprevention. J Cell Biochem Suppl, 27:106-12. 
